\title{
The establishment and early history of the South African Board for People Practices (SABPP), 1977-1991
}

\author{
Authors: \\ Huma van Rensburg \\ Johan S. Basson ${ }^{2}$ \\ Nasima M.H. Carrim² \\ Affiliations: \\ ${ }^{1}$ Chief executive officer, South \\ African Board for People \\ Practices, South Africa \\ ${ }^{2}$ Department of Human \\ Resource Management, \\ University of Pretoria, \\ South Africa \\ Correspondence to: \\ Nasima Carrim \\ Email: \\ Nasima.carrim@up.ac.za \\ Postal address: \\ Private Bag X20, Hatfield, \\ 0028, South Africa \\ Dates: \\ Received: 01 Sept. 2010 \\ Accepted: 23 Mar. 2011 \\ Published: 11 Oct. 2011 \\ How to cite this article: \\ Van Rensburg, H., Basson, \\ J.S., \& Carrim, N.M.H. (2011) \\ The establishment and early \\ history of the South African \\ Board For People Practices \\ (SABPP) 1977-1991. SA \\ Journal of Human Resource \\ Management/SA Tydskrif vir \\ Menslikehulpbronbestuur, \\ 9(1), Art. \#322, 12 pages. doi: \\ 10.4102/sajhrm.v9i1.322 \\ Note: \\ With the permission of the \\ SABPP, the researchers used \\ all relevant documents, like \\ minutes, correspondence, \\ newsletters, annual reports, \\ files not in the public domain \\ and newspaper clippings that \\ the SABPP has, as sources in \\ recording this history.
}

C 2011. The Authors.

Licensee: AOSIS

OpenJournals. This work

is licensed under the

Creative Commons

Attribution License.
Orientation: Human resource (HR) management is recognised as a profession worldwide, especially in countries that are forerunners in the field.

Research purpose: The main purpose of this study is to record the historical development of HR management as a profession. This study will provide a platform for evaluating the professional standing of HR management in South Africa.

Motivation for the study: The motivation for the study is to record the historical development of HR management in South Africa because this is long overdue.

Research design, approach and method: The researchers achieved triangulation by examining archived documents they obtained from the South African Board for People Practices (SABPP) and semi-structured interviews with five founding members of the SABPP who were involved during the whole period of the study. The founding members also verified the researchers' interpretations of the information they obtained from the documents and the interviews. The researchers used content analysis and coding to analyse the data they obtained from the archived documents and the semi-structured interviews.

Main findings: The history of HR management in South Africa shows that it meets the four founding pillars of professionalism.

Practical/managerial implications: The study also gives HR professionals confidence because HR management is achieving recognition as a profession.

Contribution/value-add: The main contribution of the study is that it has recorded the history of HR management as a profession in South Africa properly for the first time.

\section{Introduction}

Human resource (HR) management is an integral function in all South African organisations and human resource professionals play a supporting role in them. Therefore, in order to highlight the profession's credibility, it is vital to trace the history of HR management in South Africa from its inception to where it has progressed to date. Secondly, it is imperative to ascertain whether the struggle to achieve professionalism for human resource management in South Africa has been successful.

Globalisation and a changing economy have put pressure on many organisations to see their employees as sources of competitive advantage. This has led many organisations to rethink their human resource functions (Ungerer, Herholdt \& Uys, 2009). Countries, like the United Kingdom (the Chartered Institute of Personnel and Development, or CIPD), the United States of America (the Human Resource Certification Institute, or HRCI) and Canada (the Canadian Council of Human Resource Associations, or CCHRA) have recorded the history of professionalising HR management well and recognise HR management as a profession. There is a high regard for HR management in these countries.

According to Leonard (2004), the first steps to building a national certification programme for HR professionals in the United States of America (USA) began more than 50 years ago when personnel managers worked to create a national association for their profession. Leonard (2004) continues to state that, during the organising meetings for the American Society for Personnel Administration (ASPA) in 1948, delegates emphasised the need for certifying personnel professionals.

Discussions began in 1967 on definitions of the HR profession in the USA at a three-day conference. ASPA, the forerunner of the Society of Human Resource Management (SHRM), and the School of 
Industrial Relations at Cornell University attended (Leonard, 2004). These discussions led to the establishment of the World Federation of Personnel Management Associations (WFPMA) in 1976 to assist the development and improve the effectiveness of professional people management all over the world.

In 1973, the work of ASPA culminated in the establishment of the HRCI as the regulatory body for human resources. The organisation started certifying HR professionals in 1976 (Leonard, 2004).

This was when professionalising human resources became a topic of discussion in South Africa at council meetings of the Institute of Personnel Management (IPM). The number of professionals the HRCI certified has almost doubled from 48000 in 2000 to 87000 in 2004 . This indicates the escalating value of qualifying for professional status (HRCI, 2004).

Certification, according to the HRCI, occurs on three levels. The first category, the Professional HR, is for people who have two to four years of general HR work experience. The second category, Senior Professional HR, is for people who have eight years of progressive experience and understand how businesses function. The third category, the Global Professional HR, is for those who have core knowledge of organisations' international HR activities (HRCI, 2004). As far as generalist and specialist categories are concerned, the HRCI found that more than $80 \%$ of those who applied for certification were generalists. The HRCI then decided to discontinue registering specialists in 1988. Today it only certifies generalists (Tracey, 1998).

The IPM was established in Britain in 1946. It had its origins in welfare and labour movements as early as 1913. In 1994, it merged with the Institute for Training and Development (ITD) to form the Institute for Professional Development (IPD) and gained its royal charter in 2000. Today it is the Chartered Institute of Personnel and Development (CIPD, 2007). It has two classes of membership: full or voting members and non-voting members.

Full or voting members fall into the chartered category. Its lowest level is that of Chartered Member, followed by the Chartered Fellow, which requires an upgrade from the previous level. Members achieve the highest level, that of Chartered Companion, through invitation only.

Four levels of non-voting members (Graduate, Licentiate, Associate and Affiliate) form the second class of members (CIPD, 2007). Today it has more than 128,000 members and dominates the HR landscape in the United Kingdom (UK). The CIPD acknowledges both generalists and specialists in human resources. It registers specialists in eleven categories.

Canada's first national human resources association, the Canadian Council of Human Resource Associations, was formally established in 1996. It has only one level of registration, that of Certified Human Resource Professional. The Canadian HR profession requires professional capabilities in seven functional areas of practice and an additional cross-functional area called Professional Practice in Human Resources (CCHRA, 2007).

The documents on professionalising HR management in the three examples mentioned above make it clear that four important pillars are the basis of professionalisation in the three countries. These are the 'body of knowledge' that professionals must have, 'ethical conduct', 'self regulation' and 'duty to society'. These four aspects are the pillars of a profession.

The founding history of the various professional bodies and the subsequent professionalisation of the HR profession are well recorded in the three countries. The SABPP, founded at the same time as the HRCI in the United States, has never had its history recorded.

The first author and other leading members of the SABPP are retiring from the organisation. They have first-hand knowledge of the history of the SABPP because of their lengthy tenure with the organisation. Therefore, not capturing their thoughts, knowledge and ideas about the inception and development of the organisation will leave a gap in the South African HR literature. It may not be possible to capture the history of the SABPP as accurately in the future.

Huma van Rensburg's MCom dissertation (2009) is the source of this record of the establishment and early history of the South African Board for People Practices.

\section{Research objectives}

The objectives of this study are to provide an overview of the events that led to the establishment of SABPP (1977-1981), a professional body, and to record the first years of its existence (1982-1991). From this evidence, we can ascertain whether HR management has grown as a profession and the extent of its growth.

The research objective led to the formulation of the research question: 'how did professionalism in HR management emerge in the South African context?'

\section{Research design Research approach}

Babbie and Mouton (2006, p. 28) postulate that all human beings 'are engaged in the process of making sense of their (life) worlds'. One cannot separate reality from the people who observe it. Using the ontological approach, the researchers examined the original documents of the SABPP because they contained reliable information about the establishment of HR management as a profession in South Africa. In addition, the researchers interviewed five founding members of the SABPP for their expert knowledge of the establishment of the SABPP in South Africa. 
The epistemological approach focuses on 'how we as human beings know the world' (Georgia Institute of Technology, 2008). Using an epistemological approach in the interpretivist paradigm, researchers should ignore pre-conceptions in their understanding of that world (Bryman \& Bell, 2003). The researchers in the current study believed it was necessary to investigate and interpret the history of HR management in South Africa from the information they found in original archived documents and from the points of view of the five founding members of the SABPP.

\section{Research strategy}

The researchers followed a qualitative research strategy. They used original documents of the SABPP and semistructured interviews with founding members of the SABPP for the current study.

The researchers achieved triangulation in the following ways:

- by using archived documents of the SABPP because they yielded historical information about the thinking at the time of the establishment of the HR profession in South Africa

- by conducting semi-structured interviews with five founding members of the SABPP who had helped to establish the professional body, some from the very beginning and some at a slightly later stage

- by asking the five founding members to give their comments on how the researchers interpreted the information they gained from the archived documents and the semi-structured interviews they conducted.

\section{Research method}

\section{Research setting}

The researchers perused the original documents at the premises of the SABPP. Most of the founding members of the SABPP are no longer with the board and the researchers contacted and conducted the interviews at their homes or workplaces.

\section{Entrée and establishing the role of the researchers}

The first researcher is chief executive officer (CEO) of the SABPP. Therefore, the researchers had access to the original documents that traced the history of HR management in South Africa. The researchers also knew which of the founding members would be able to contribute to the study. The researchers had access to the contact details of the founding members and had contacted them personally to explain the aim of the study and to obtain permission to interview them.

One of the researchers is in a perfect position to do this study, having been the registrar and later chief executive officer of the regulatory body in South Africa for 21 years of the 28 years of the board's existence. Therefore, someone who has lived through most of the board's history conducted the research into the history of professional human resource management in South Africa. However, the researchers made every effort to remain objective and allow for other perspectives through interviews with primary stakeholders in the SABPP.

\section{Sampling}

The researchers used purposive sampling to identify the documents they would use to trace the history of HR management in South Africa. They also used purposive sampling to select the research participants. They chose five founding members of the SABPP for their in-depth knowledge of the history of the SABPP and the beginnings of HR management in South Africa.

\section{Data collection}

The researchers collected data from various sources. These included minutes, filed correspondence, newsletters, annual reports, committee files and others not in the public domain as well as newspaper clippings the SABPP had. This is the first recording of the history of the SABPP from documents not in the public domain. It is an opportunity to safeguard historic information, which may otherwise have been lost to the HR community, and to understand how the events that led to the establishment of the SABPP in 1982 unfolded.

The researchers also conducted semi-structured interviews with founding members because they could provide indepth information about the history of HR management in South Africa.

Finally, the researchers provided the information, which they had collected from the archived documents, and the semi-structured interviews to the five founding members for their comments.

\section{Data recording}

The researchers extracted relevant data from documents the SABPP had archived. They also made audio recordings of the interviews, and then transcribed and analysed them.

\section{Data analysis}

The researchers conducted content analysis to extract themes from the archived documents and to identify themes from the semi-structured interviews. Their content analysis included coding and classifying data (Hancock, 2002).

According to Trochim (2006), coding is a process of categorising qualitative data and describing the implications and details of the categories. Open coding created new codes for the transcripts, the archived documents of the SABPP and the semi-structured interviews. The researchers identified a list of categories from the transcripts and initially used open coding to identify themes.

\section{Strategies to ensure the quality of the research}

Researchers have to ensure the credibility, transferability, confirmability and dependability of data when they conduct qualitative research. 
In order to show that their data was credible, dependable and confirmable, the researchers collected data from as many sources and situations as possible so that the picture they provided was as complete and rich as possible.

The researchers perused the archived information and interviewed founding members to establish their understanding of the history of HR management in South Africa. They asked the founding members to comment on the researchers' interpretations of the information in the archived documents and that they obtained during the semi-structured interviews. The researchers improved transferability because they provided thorough descriptions of the development of the history of HR management in South Africa. For transferability, other researchers will have to look at the context in which HR management is practised and to provide a history of HR management within that context.

\section{Results}

\section{Establishing the South African Board for People Practices, 1977-1991}

The researchers undertook an historic overview of the development of professionalism in human resources in South Africa. They concentrated specifically on the establishment and early history of the SABPP. Today, the SABPP is the professional registering body for human resource professionals and the statutory quality assurance body in terms of the South African Qualifications Authority (SAQA) Act.

\section{An evolving profession, 1973-1976}

In South Africa, the professionalisation of human resource management became a topic of discussion at IPM council meetings between 1973 and 1976. At this time, the role of personnel managers was taking shape on the international stage. During the same period, there was a concomitant awakening to the fact that the role of the human resource practitioner would become increasingly important in South Africa. According to Wilhelm Crous, CEO of the IPM at the time, the 1973 strikes in the sugar industry showed that HR management was not professional enough to handle the crisis. There was also an awareness of the human resource practitioner's obligation to society and the economy.

\section{Laying the foundations, 1977-1980}

Extensive consultations with top HR managers and business people began in about 1977. Recognised practitioners in the field, like Dick Sutton and Piet Rossouw, members of the first board of the SABPP, and Piet van der Merwe, the director general of labour at the time, lent their support to the drive to professionalise the personnel field. In giving some of the background to the period, Cadre (Dr) Ray Eberlein, another member of the first board of the SABPP, commented that South Africa had isolated itself from the outside world. However, global imperatives and the need to develop parallel structures was a factor in establishing the board. Garry Whyte, the acknowledged founding father of the board and its first chairperson, saw the establishment of the SABPP as providing a 'home' for young entrants to the HR field.

In the researchers' interview with Wilhelm Crous on background issues, he explained that the original idea was to develop legislation to establish a professional registering body for personnel practice and that the IPM and government would then launch the body together. Government was not opposed to the idea of professionalisation but required that the profession established itself first. This meant the IPM established the SABPP without government buy-in.

\section{Establishing an ad hoc committee}

The IPM council established the forerunner to the first board by appointing the 'Ad Hoc Committee on Professional Recognition for Personnel Practitioners' in 1978. This ad hoc committee started work in 1978.

\section{The research}

Langenhoven and Daniels (Langenhoven \& Daniels, 1980) initiated research to define a 'profession' at the University of the Free State and Nelson Mandela University (National Institute of Personnel Research, or NIPR). The Langenhoven study, 'An investigation on the professionalisation of expert personnel management', appeared in 1980. Langenhoven's research on the importance of professionalising human resources was significant in the whole process.

It was not possible to prohibit people like line managers from doing personnel work. Therefore, the value of professional registration lay in the fact it would 'identify people who meet certain qualification requirements and who submit to certain standards of conduct'. Langenhoven's study expressed the view that a regulatory body would be able to guide tertiary institutions on the type of training it required. Furthermore, registration, and the status that it conferred, would make it worthwhile for personnel people to acquire the necessary training.

Langenhoven's research on the importance of professionalising human resource management was significant in the whole process. A summary of the major findings of Langenhoven's (1980) study follows:

- personnel staff constituted a relatively small percentage of the total staff establishment (0.82\% in 1975 and $0.92 \%$ in 1980), but it was clear that they were increasing more rapidly than the total staff complement

- a relatively small percentage of the staff during the period was qualified to perform expert personnel work, but most $(60.9 \%)$ had received no post-school training

- clerical and semi-professional work took up too much time instead of professional work, which could make a more valuable contribution to organisations

- respondents rated consultation with, and services to, managers as the function where personnel practitioners could make the greatest contribution; planning, 
implementing and evaluating personnel systems and developing objectives and policies on personnel matters followed

- as far as the relative importance of various types of knowledge and experience for personnel practitioners was concerned, respondents rated knowledge of an applied behavioural science as most important, followed by practical training and experience in personnel work, knowledge of economic or administrative sciences, knowledge of relevant labour and industrial legislation and anthropology

- the most desirable training course seemed to be Industrial Psychology III, Business Economics or Industrial Sociology II, Labour Law I, Statistics I, Public Administration I, Applied Anthropology I and Economics I.

\section{The establishment of the South African Board for People Practices, 1981}

The ad hoc committee recommended establishing the SABPP to the council of the IPM in 1981. The committee decided on no discrimination a premise and members of previously disadvantaged groups have been elected to all SABPP boards since its inception. In fact, previously disadvantaged groups had the most elected members on the board in the early 2000 s.

The final meeting of the ad hoc committee, before the establishment of the SABPP, was held on 27 October 1981 and the board was appointed in September 1982 under the chairmanship of Garry Whyte. A list of persons to be invited to serve on the first board was forwarded to the president of the IPM at the time, Dr Johan Gouws.

The draft charter and regulations were submitted to IPM members and put to the vote. Forty-eight per cent of the members responded. Of these, $92 \%$ voted in favour of establishing a separate regulatory body for registering HR practitioners and $8 \%$ voted against the proposal.

The members agreed that, in the interim, the South African Board for Personnel Practice would operate from the offices of the IPM. However, as soon as funds allowed, the SABPP would seek alternative accommodation. The members gave Whyte and Crous permission to begin the procedure of choosing a suitable heraldic device for the board.

Garry Whyte announced the establishment of the board to government in letters to the director general of manpower, the chairman of the National Manpower Commission, the chairman of the National Training Board and in the IPM Journal in 1981.

The first interim board accepted its mission, philosophy and strategy:

- Mission: To establish, direct and sustain a high level of professionalism and ethical conduct in personnel practice.

- Philosophy: To enable those engaged in the personnel profession to make a significant contribution to the organisation, in terms of its management and utilisation of personnel; to the individual, in the realisation of his or her potential, in terms of his or her aspirations; and to the community at large, in terms of an enhanced quality of life.

- Strategy: To promote, direct and influence the development of the personnel profession; to set competency standards for the education, training and conduct of those engaged in the profession; to advise involved parties on the development and attaining of those competencies and to evaluate such attainment.

At a meeting at the University of Stellenbosch in June 1981, the interim board discussed and proposed registration levels and categories and suggested that board should allow the following three specialist categories of registration:

- 'Personnel Management' (which later became the 'Generalist' category)

- 'Labour Relations' (which later became 'Employment Relations')

- 'Training and Development' (which later became 'Learning and Development').

\section{Appointment of the first board, 1982}

The first board of the SABPP met on 29 November 1982. The appointed board members who attended were $\mathrm{Mr}$ Garry Whyte (chairman), Prof. H.P. (Langie) Langenhoven (vice chairman), Dr Peter Berry, Prof. Johann Coetzee, Mr Wilhelm Crous (registrar), Mr Willem de Villiers, Cadre (Dr) Ray Eberlein, Dr Johan Gouws (then president of the IPM), Mr Cyril Jantjies, Ms. Denise Jordan, Mr Japs Jacobs, Mr Ray Kwatsha, Mr David Lamola, Mr Bulumko Msengana, Dr Gordon Nelson, Mr Wells Ntuli, Mr John Poppleton, Mr Piet Rossouw, Prof. Dick Sutton, Prof. Blackie Swart and Ms. Judy Townsend.

Prof. I. v. W. Raubenheimer was appointed to the first board to replace Mr Ray Kwatsha, who had been transferred to America.

\section{A registrar for the board}

The first order of business was to appoint Mr Wilhelm Crous as part-time registrar of the board, in his individual capacity and not as director of the PM, with the proviso that the appointment would be an interim one and that, as soon as funds allowed, the board would appoint a full time registrar.

\section{The board establishes committees}

Te first committees the board established were the registration committee, with Dr Ray Eberlein as its first chair, the education and training committee under the leadership of Prof. H. Langenhoven, the finance committee under the chairmanship of Mr Garry Whyte and the disciplinary committee under the leadership of Mr Willem de Villiers.

\section{The work of the South African Board for People Practices commences, 1983-1984}

The board invited registration for the levels of Practitioner, Technician and Candidate. The fees to register for these three 
levels were R15 for Practitioner, R15 for Technician and R10 for Candidate.

\section{The first code of conduct}

The board accepted the code and ethics as laid down in its charter:

Registered members of the personnel profession are obliged to uphold certain standards in their practice, both in the interests of the public and of their calling. These include:

- conducting themselves at all times in keeping with the dignity, standing and reputation of the profession

- doing their work to the best of their ability and so discharging their duties to employers, employees and clients

- not undertaking work for which they are inadequately trained or experienced

- not canvassing or soliciting for work in an improper way

- refraining from presenting themselves or advertising their services immodestly or in any way undermining to the profession

- refraining from any conduct arising from malice or negligence that would harm, directly or indirectly, the business, reputation or prospects of any other person or organisation

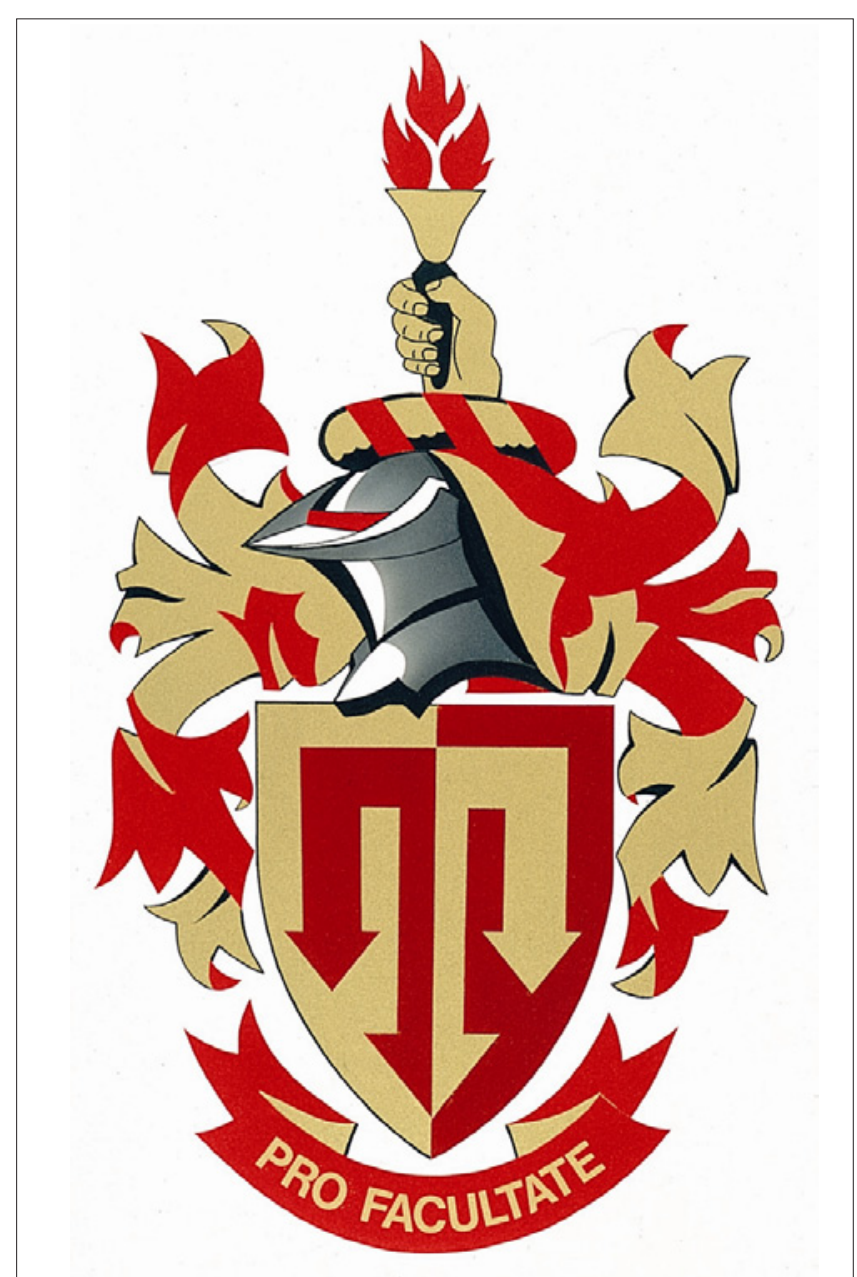

FIGURE 1: The heraldic device of the South African Board for People Practices.
- refusing to disclose confidential information acquired in the course of their professional practice (In a court of law, professional confidence may be breached only under protest and at the direction of the presiding officer)

- always obeying the rules and conventions, as prescribed by the Board, in their professional life.

\section{Heraldic device}

The board assigned the design a heraldic device for the board to Whyte and Crous. They completed it and registered it with the Bureau of State Heraldry on 20 February 1984.

\section{A description of the coat of arms of the SABPP follows:}

- Arms: Per pale Or and Gules, a bar couped enhanced conjoined to three pallets couped and barbed to base, counter-changed.

- Crest: A dexter hand issuant holding a torch erect, Or, handle Sable, enflamed Gules.

- Wreath and mantling: Or and Gules.

- Motto: Pro Facultate.

An explanation of the coat of arms follows:

- Arms: The bar from which the arrows are pended represents the guarding of professional standards. The three arrows represent the principal specialist categories of personnel practice: Training and Development, Industrial Relations and Personnel Services. They also represent the three categories of registration: Candidate, Technician and Practitioner. The arrows point downwards to show depth of professional knowledge. The colour divisions of the shield represent the transfer from non-professional to professional standing.

- Crest: The hand symbolises 'manpower'. The torch symbolises the board's promotion of education and training in the field of personnel practice.

- Wreath and mantling: Tincture has no special meaning in heraldry. However, the rule of tincture states that colour should not be placed on colour or metal on metal. The board chose red as the colour and gold as the metal. Both are primary heraldic tinctures.

- Motto: 'According to one's ability'.

\section{The Institute of Industrial Psychology}

The board discussed its relationship with the South African Medical and Dental Council's Institute of Industrial Psychology at its meeting of 12 September 1983. The board agreed to establish a special committee to investigate an agreement between the SABPP and the Institute of Industrial Psychology about a specialist category. It decided to establish a specialist category of 'Psychologiae' under both the Practitioner and Technician levels for industrial psychologists and psychometricians respectively. Prof. Raubenheimer, who was the chairman of the Institute of Industrial Psychology, conveyed the satisfaction of the institute with this decision.

\section{Registration commences}

The registration process began in early 1983. The interim board approved the specialist categories that follow: Training 
and Development, Industrial Relations, Recruitment and Selection, Personnel Services, Education and Research as well as Psychologiae. The interim board asked all members to submit their applications for registration. The interim board agreed to reserve the first 21 places for members of the board.

\section{Recognition of the Institute of Personnel Management Diploma}

The board saw recognising the IPM Diploma, so that IPM diplomats could register, as an important goal. The board agreed to submit the IPM Diploma to the Human Sciences Research Council and to the SABPP's education and training committee to evaluate its education level and relevancy.

The IPM Diploma should have been recognised as an M+3 level qualification. A higher diploma, which could have been acknowledged at M+4 level, should have been introduced. However, these developments never happened.

Universities of technology and other qualifying institutions should have offered a higher diploma at M+4 level. Introducing a B Tech degree in HR met this need.

\section{Furthering statutory recognition, 1985-1986 The Draft Personnel Practice Bill}

From its inception, the SABPP saw official recognition for the HR profession as a major goal. After its inauguration in 1982, the board immediately began working towards statutory recognition. It addressed a memorandum to the director general of manpower. It outlined the implications of statutory recognition for human resource professionals. The board spent much of its time drawing up a charter and regulations in preparation for statutory status. Government Gazette No. 9957 Vol. 244 of 4 October 1985 published the first charter of the board.

At the September 1983 meeting of the board, Garry Whyte reported that a meeting had been held with Dr Piet van der Merwe of the Department of Manpower in Cape Town on 18 June 1983. Dr van der Merwe had urged the SABPP to prepare draft legislation for statutory recognition for 1985. The board welcomed this proposal and agreed to ask Dr van der Merwe to go through the legislation with the committee it had established to deal with the matter.

Garry Whyte arranged a meeting with the Minister of Manpower, P. du Plessis, to negotiate passing the Personnel Practice Bill. Some lobbied against the bill because it would make human resources exclusive and expensive. Cabinet decided that, in the climate of deregulation at the time, it would not go ahead with statutory recognition. The minister of manpower officially declined to table the bill in Parliament.

By the end of 1986, the number of registered practitioners stood at 3491.

\section{Voluntary professionalism, 1987}

A letter from the board's first registrar, dated 4 February 1987, read:
As it now appears that statutory recognition will not be realised within the short or medium term, the Executive Committee recommends that the SABPP registers as a company not for gain. The Draft Legislation has therefore been converted back to the original Charter of the SABPP.

(Crous, 1987)

It had become clear that the board would have to rethink its entire position, which up to that point had revolved around statutory recognition. Therefore, it investigated and discussed voluntary professionalism. It visited the National Productivity Institute (NPI) and the National Occupational Safety Association (NOSA). The minutes of the February 1987 meeting reported that both these organisations had official recognition without statutory status.

The board then investigated establishing the SABPP as a Section 21 company. However, a board meeting of the SABPP did not recommend this step and it remained an Association Not for Gain. The SABPP launched an intensive public relations campaign to inform employers of its work and aims.

The board was restructured to make room for representatives from other bodies.

The IPM appointed three institute representatives:

- two members from the Institute of Personnel Management (IPM)

- one member from the Institute of Industrial Psychology (IIP).

Five employer organisations appointed representatives:

- one member from the Federated Chamber of Industries (FCI)

- one member from the Afrikaanse Handelsinstituut (AHI)

- one member from the National African Federated Chamber of Commerce (NAFCOC)

- one member from the Commission for Administration (CoA)

- one member from the Associated Chamber of Commerce (ACC).

The Ministry of Manpower appointed two ministerial representatives.

The Sunday Times of 20 November 1988 reported this change to the structure of the board:

The most recent development is that representatives of the Ministry of Manpower and all five major employer organisations have joined the SA Board for Personnel Practice.

Inclusion of these members has added to the board's ability to influence the development of the personnel profession, of which it is the regulating body.

(Sunday Times, 20 November 1988)

First election of a South African Board for People Practices The SABPP posted the notice of the election of the second board to registered professionals on 20 February 1987. As the 
IPM had appointed the first board, this was the first election the SABPP would hold.

The election proceeded smoothly and the following board members became the first elected members: Mr M.B. Burgess, Mr W.S. de Villiers, Dr J.S. Gouws, Mr M.S. Khumalo, Prof. H.P. Langenhoven, Mr Z.W. Ntuli, Prof. I. van W. Raubenheimer, Mr P.W.G. Rossouw, Mr M. Thantsa, Mr G. van der Straaten and Mr G.S. Whyte (unanimously re-elected as chairman of the board).

Nominations for representatives from other bodies at that stage included: Cdre. R. Eberlein and Prof. C.D. Pottas (IPM), Dr C. Schilbach (IIP), Mr N.E. Seaber (Assocom) and Mr T. van den Bergh (FCI).

The first meeting of the board confirmed the following nominations: $\mathrm{Mr}$ J.H.C. Kastner (Commission for Administration), Messers K.W. du Toit and R.M. Dilman (manpower), Mr M. Sebesho (NAFCOC) and Mr G.M. Albertyn (AHI).

The composition of the second board was only finalised in early 1989 when Cdre Ray Eberlein replaced Mr Mike Burgess after his resignation as an elected member. $\mathrm{Mr}$ Wilhelm Crous resigned as registrar and became a member of the board as the representative of the IPM.

A request was received for the SABPP to allow representation on the board for each specialist category so that their interests could be adequately monitored. The SABPP decided that this would make the board too large and rejected the suggestion. It rejected another suggestion, for representation of higher education institutions with HR programmes, for the same reason.

\section{An Human Resource candidateship}

A candidate programme, designed for the South African Defence Force (SADF) under the leadership of Cadre (Dr) Ray Eberlein, was formally submitted to the education and training committee for approval. The board accepted the SADF programme, which stretched over a two-year period. It communicated this decision to the SADF and the minutes reported that Gen. S Meyer (chief of staff personnel) wrote to thank the board.

\section{Basics reviewed, 1988}

At the first meeting of the fully constituted second board, the meeting elected the executive committee. It comprised the chairman, vice chairman and registrar.

\section{Objectives for the 1988-1991 term of office}

The SABPP set objectives, which the board approved, for the 1988-1991 term of office. They were to:

- identify, analyse and verify the acceptability of the formal qualifications that are available locally to applicants

- specify the types of experience that are acceptable for registration
- develop a formal examination for doubtful candidates

- publish and market the benefits of registering

- conduct a campaign to register candidates who are studying in the HR field.

The board then attended to various aspects of professionalism. It investigated the issue of granting post-nominal designations and decided on three pre-conditions:

- a well-established registration process

- clearly defined, and tested in practise, standards of registration

- registration of a significant number of people.

The board decided that these conditions had been met and proceeded with official applications. It followed this by announcing officially that it had applied for legal protection of the names 'Registered Personnel Practitioner (RPP)' and 'Registered Personnel Technician (RPT)'.

\section{Proposed board examination}

The board held extensive discussions about the registration criteria for HR practitioners. On inception, the board had introduced a 'grandfather' clause to accommodate senior HR practitioners who did not have the necessary qualifications for the initial intake of registrations.

With the termination of the grandfather clause, planned for the end of 1988, it became clear that some mechanism to deal with people practising in the personnel field without qualifications might always be necessary. Registration based on experience only did not meet this need.

The board tabled the introduction of a board examination for the first time and decided to study the process used for chartered accountants. The board would continue, through the years, to deal with applicants who did not have relevant academic qualifications. Today, the board uses recognition of prior learning (RPL).

\section{Personnel management vs. human resources in the board's name}

It is clear from the minutes of the board that it had received requests, from as far back as 1978, to replace the term 'personnel' with the term 'human resources'. Cdre. Ray Eberlein, chairman of the registration committee, produced a paper on the subject.

A brief summary of the board's conclusions appeared in its 1988 newsletter:

We believe that 'Human Resource Management' is a general description of those activities carried out in an organisation, by any manager, designed to optimise the contribution of the Human Resource to the achievement of the organisation's objectives.

We believe that the term 'Personnel Management' is a specific description of those activities carried out by qualified specialists, designed to apply a defined body of knowledge (drawn from the Social Sciences) to the maintenance, utilisation and development of the Human Resource within the work environment. 
Furthermore, your Board is reluctant to use the term 'Management' in the context of its name, since many of the specialists referred to above are not managers: in fact, the only person who should logically carry the title 'Personnel Manager' is a person who exercises line authority over others within the personnel function.

(Newsletter, 1988)

The board announced its decision to continue using the name 'South African Board for Personnel Practice' to the fraternity. It finally changed its name to the 'South African Board for People Practices' in 2009.

During this time, the board reviewed its disciplinary procedures and ethical code. The board confirmed that its code covered all aspects of the American HR code and that of the South African Psychological Association. At the time, the board regarded these criteria as sufficient for a code for the HR profession.

A survey of top executive salary increases and other benefits showed that personnel executives had soared from bottom place to top (percentage growth) in just four years, according to an article that Stan Kennedy published in the Saturday Star of 15 October 1988. The information came from a survey that PE Corporate Services carried out and included chief, financial and marketing executives. It showed a growing emphasis on the 'people side of business'.

The article also quoted Garry Whyte, the chairman of the $\mathrm{SABPP}$, as saying:

The Board will no longer register candidates unless they meet the registration requirements for a personnel practitioner which will comprise of a four-year academic qualification, recognised by the controlling board of SABPP, as well as a two-year supervised candidateship of practical training and experience in the field.

(Garry Whyte, the chairman of the SABPP)

In the interview, which the editor of the SABPP newsletter requested, Whyte also said:

The skills of personnel management are a critical issue in the private and public sectors. There is a new breed of personnel manager. The work is much more sophisticated and the issue of competence is vital.

(Garry Whyte, the chairman of the SABPP)

The board decided to promote liaison with tertiary education institutions that offer qualifications in human resource management, not in an attempt to dictate to the education institutions, but rather to keep them informed of the requirements in the marketplace where their students would work once they qualified.

The board appointed Prof. Chris Pottas to undertake a survey to establish exactly what educational qualifications the institutions were offering in the HR field. The board discussed registering the HR programmes of higher education institutions.

\section{A period of consolidation, 1989}

The board expanded its executive committee to include the chairmen of each of its committees.

\section{Establishing an upgrade process}

At its first meeting of 1989, the board considered establishing a bridging facility to allow a Personnel Technician to upgrade to Personnel Practitioner. It proposed and accepted:

- recognition of the IPM Diploma as an M+3 level qualification and to introduce a higher diploma that it could recognise at $M+4$ level

- that technikons (now universities of technology) and other qualifying institutions should offer a higher diploma at $\mathrm{M}+4$ level

- that a person registered as a Personnel Technician, and who had obtained a recognised higher diploma that the board recognised, would be able to apply for an upgrade to Practitioner level.

In exceptional cases, the board might make a board examination available. It appointed an examination commission and set stringent entry criteria. These stipulated that the person had to be a graduate and had to have at least 10 years of relevant experience.

The board announced these decisions by newsletter in the IPM Journal and to the various tertiary institutions by letter.

The board decided that it would automatically register the students of those universities that had submitted their programmes to the board for approval. The board approached universities with an invitation to apply for accreditation. The first university to accept this invitation was the University of Pretoria, through Prof. Leopold Vermeulen. In November 1989, the board was able to report that six of South Africa's leading universities, as well as the IPM, had asked the board to accredit their personnel programmes.

\section{Appointment of first full-time registrar}

After an extended period of recruitment, the board appointed its first full-time registrar, Huma van Rensburg, on 1 May 1989. She took over from the part-time registrar, Wilhelm Crous. The board occupied a boardroom within the IPM suite of offices.

\section{Statutory recognition removed from the agenda}

The minutes of 18 July 1989 recorded a decision to remove the matter of statutory recognition from the agenda of the board. However, the minutes noted that it might be raised again should a more positive climate develop. The board also approved a suggestion that it has an annual meeting with the minister of manpower.

South African Board for People Practices participation in World Federation of Personnel Management Associations survey

In 1989, the participation of the SABPP in the survey of the WFPMA was another accomplishment. The survey rated South Africa as the best in its approach to professionalism in personnel practice. It quoted Whyte as saying that South Africa's input to the WFPMA report was markedly different from the rest of the world because of several factors that 
affected its thinking on personnel practice. The WFPMA report highlighted that African representatives rated academic and professional training far higher, on a list of major concerns, than any other region.

\section{Register for training instructors}

During the period of consolidation, the board discussed establishing a separate register for training instructors. The National Training Board supported this move, on condition that the SABPP maintained its independence. Despite this promising start, the matter went no further and trainers remained on the general register. The board would review the matter when the numbers of trainers registering with the SABPP increased substantially.

\section{The South African Board for People Practices report at the Institute of Personnel Management Convention}

Whyte gave an extensive report on the work and decisions of the board at the IPM convention of 1989. He mentioned four main accomplishments:

Firstly. We in the Personnel Fraternity now UNAMBIGUOUSLY regard ourselves as professional people; and concepts like 'professionalism' and 'professional standards' have assumed a central role in our thinking. This was not the case when the Board was established in 1982.

Secondly. We now comprehend, very clearly, the difference between the term 'Personnel Practice' (which describes our unique role as functional specialists), and the term 'Personnel Management' (which refers to the generic role of managing people at work - a task performed by almost every executive). This was also not the case in 1982.

Thirdly. And in similar vein, words like 'Practitioner', and 'Technician', and 'Generalist', and 'Specialist', have become common currency in the language of our profession and it was the Board that formulated and propagated the concepts underlying these words.

Fourthly. And with increasing frequency, one finds in job descriptions, in selection specifications, and in job vacancy advertisements, reference to registration with the Board as an expression of desired performance standards and the concomitant of this is that personnel people are increasingly making reference in their CVs to the fact of their professional registration.

(Garry Whyte, the chairman of the SABPP)

By 1991, the number of registered professionals had reached 3554.

\section{Accreditation and research, 1990 Accreditation of tertiary training institutions}

Audit teams conducted the first audits of the curricula of tertiary training institutions. A senior academic from another institution led each audit. Each audit team comprised the senior academic, the registrar of the board and at least two senior practitioners in the field.

The board announced that it had accredited the curricula of some universities in August 1990:
On recommendation of the Education and Training Committee, the board accredited the curricula of the following universities for a period of three years, to the end of 1993:

University of Fort Hare, University of the Free State, University of Port Elizabeth, University of Potchefstroom, University of Pretoria, University of Stellenbosch, University of South Africa and University of the Witwatersrand.

(Board announcement, August 1990)

Technikons (now universities of technology) and the Institute of Personnel Management

The board accepted the diplomas in personnel management that the technikons (universities of technology) and the IPM offered for registration to Personnel Technician. Leading academics in the field, like Prof. Naas Raubenheimer, Prof. Stephen Bluen, Prof. Leopold Vermeulen and others, attended a meeting in 1991. After this meeting, the board accepted the B.Tech that technikons (universities of technology) offered for registering practitioners.

\section{Reporting on human resources in company annual reports}

Garry Whyte became a strong proponent for the full disclosure of human resource data in the annual reports of companies.

Whyte stated, in early 1990, that an annual report would become a much more powerful tool if it provided information on issues like labour productivity, relations with unions and workforce morale. He went on to say:

Some companies pay lip service to black advancement. But what are they really doing to address the problem? It is a core issue for the future viability of every South African organisation.

(Garry Whyte, the chairman of the SABPP)

The board published its first formal annual report (for the 1989 fiscal year) to express the board's support for transparency in all its processes and finances. The board has published these reports annually ever since.

\section{First board examinations}

The board thought that a board examination to enable people who satisfy other stringent criteria to become personnel practitioners was essential. Prof. Chris Pottas, chairman of the board's education and training committee, said in a speech to the board:

The decision in no way means a lowering of registration standards. In fact, the introduction of a Board examination is designed to ensure the maintenance of the highest professional standards.

(Prof. Chris Pottas, speech to the board)

The first candidates wrote the board examinations in 1990 as a way of entering the professional ranks of very experienced HR practitioners who lacked the necessary academic qualifications. The board applied admission requirements strictly and accepted only nine examinees for the first group. 


\section{First position paper of the board - A Generic Competency Model}

The SABPP, together with Eskom, published a Generic Competency Model for human resource practitioners in 1990. This work was fundamental to the later work of the Standards Generating Body for HR Management and Practice for delineating the field and writing the first unit standards.

\section{Bio-demographic survey}

A bio-demographic survey of registered practitioners began in 1990 and the board received 2065 returns. It published the results in a newsletter dated November 1991. The profile that emerged showed that a large majority of registered human resource professionals (76.24\%) had formal qualifications. Males still dominated the profession and Afrikaans (50.6\% and English (45\%) were the languages most professionals used.

It would be interesting to do a comparative study of today's registered professionals. When the board conducted the survey, it seemed that South African HR practitioners, who were registering as professionals, compared very favourably with overseas colleagues and were, on the whole, better qualified.

What is unique about this development has been the emergence of a large number of young and well-qualified black HR practitioners who presented themselves for professional registration. HR management is the one profession in South Africa that is well on its way to becoming the most racially representative profession.

\section{Serving on the Certification Council for Technikon Education}

Because the SABPP accredited technikons (universities of technology) to train human resource practitioners, the Certification Council for Technikon Education (Sertec) invited the SABPP to serve on its certification council. The board served on this body until the South African Qualifications Authority (SAQA) and the Higher Education Quality Council (HEQC) replaced it.

\section{The end of an era}

The first chairman of the board, Garry Slessor Whyte, passed away on 27 February 1991. The essence of his last public speech, which he made at the end of 1990, was that business leaders and personnel practitioners should make a concerted effort to advance black people to director and managerial positions and not pay lip service to black empowerment.

The board elected Wilhelm Crous as its second chairman in 1991.

This marks the end of the official record of the establishment and early history of the SABPP from 1977-1991.

Many of the founding members of the SABPP are no longer with us. The researchers distributed this history to five people, who were present at the beginning or joined in the work during the first years, for input.

Those who read the recorded history and established the veracity of the record were:

- Dr Ray Eberlein, member of the ad hoc committee established in 1978 to form the SABPP

- Prof. Johann Coetzee and Judy Norris, members of the first board of the SABPP

- Wilhelm Crous, CEO of IPM at the time and the first parttime registrar of the SABPP

- Ivan Lätti, who represented the IPM on the board of the SABPP in the early years.

\section{Suggestions for further research}

This is by no means a comprehensive history of the SABPP. However, it traces the history of the SABPP from the first discussions to the death of the founding father, Garry Whyte.

The researchers recorded the history within the larger context of the dissertation on the professionalisation of HR management worldwide and the concurrent developments in South Africa. The major emphasis in the early history was the establishment and development under the guidance of the founding father of the SABPP, Garry Whyte.

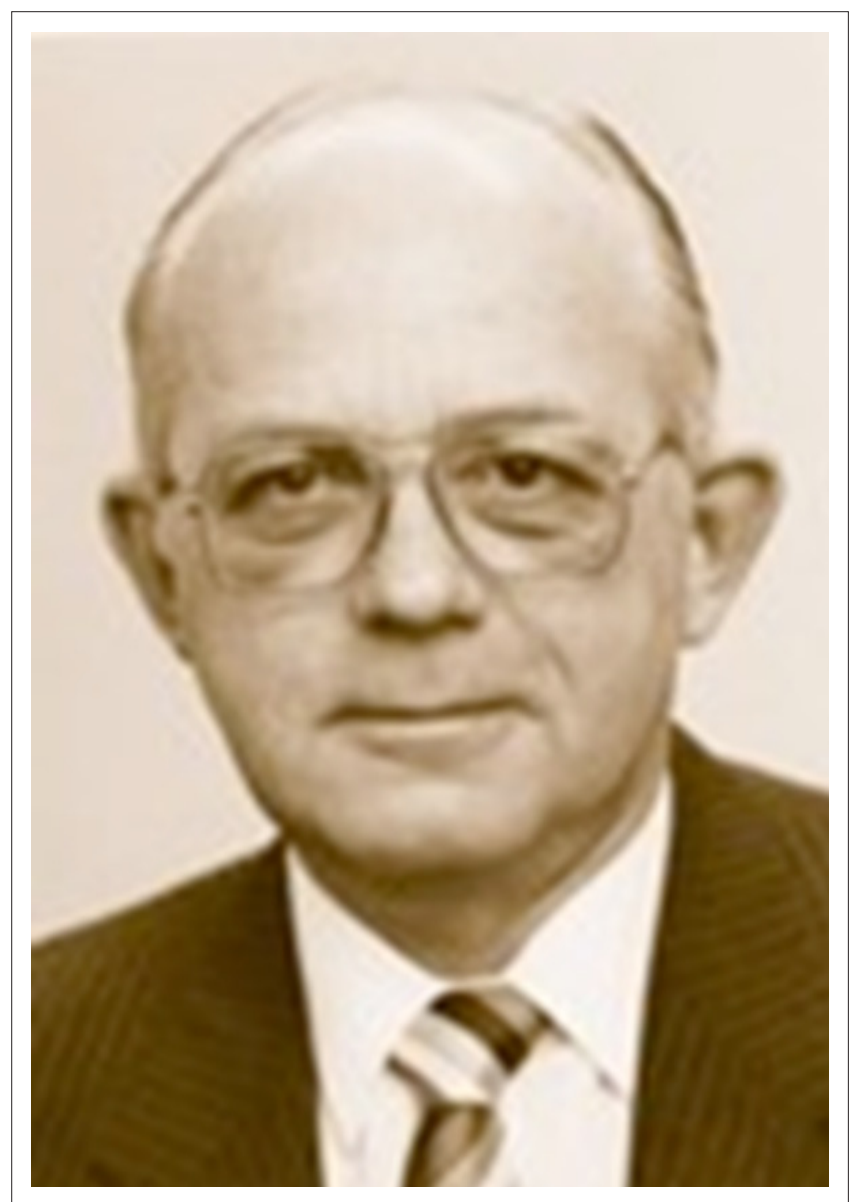

FIGURE 2: Garry Whyte. 
With his death in 1991, a new era dawned for the board. The researchers recorded the era until 1990 from fragmented documents. After 1990, the board compiled and published annual reports and they became the records of board happenings, decisions and events after 1991 (Van Rensburg, 2009).

The researchers recommend that further research is done to cover the years 1991-2011. It should record how the sociopolitical changes of the nineties affected the board, how the development of the National Qualifications Framework influenced the board to seek accreditation as a statutory quality assurance body and how research became a major thrust.

\section{Conclusion}

If one considers that professions, like the legal and medical professions, took hundreds of years to develop to their current levels of sophistication, one needs reminding that HR management is a fledgling profession. Professionalisation of HR management in South Africa is growing apace. Its role, in taking responsibility for good governance and ethics, continued professional development and research, has created an awareness of the benefits of professionalisation to the industry and to the country as a whole. HR management does not grow in isolation, but in conjunction with the management and decision sciences in the economy. Industrial psychology is acknowledged as the mother science for HR management in the South African context.

Nevertheless, the conclusion that HR management is a profession in every sense of the word is inescapable. One of the aspects of the dissertation, which is the basis of this article, was an investigation into the nature of professionalism by looking at the origins and foundations of four major professions (engineering, medical, legal and accounting). The researchers identified the following fundamental principles in these professions:

- mastery of a complex body of knowledge and skills

- a commitment to integrity and morality through a code of conduct

- autonomy in practice and self-regulation

- acceptance of a duty to society.

HR management measures up to every one of these criteria. There is every expectation that the HR profession will consolidate and build upon the work it has done over the past three decades.

With ethics and registration criteria, standards and processes in place, the board has achieved statutory status as the accredited quality assurance body for HR management in South Africa.

It is currently concentrating on a seamless electronic Continued Professional Development (CPD) system and has an impressive research agenda. It has either completed 16 opinion papers, best practice papers and case studies or they are in the pipeline. It also published a book, Wisdom from HR Mentors, in March 2011 (Meyer, 2011).
To meet the ideals of the founders of professional HR management in South Africa, it is important for the board to become visible and to convince industry and government that supporting the continued professionalisation of $\mathrm{HR}$ management is in their best interests.

HR management is a specialist profession. It has a pivotal role to play as caretaker of the most valued asset in business - people. Fill this profession with practitioners who have scientific expertise and competence, as well as a deeply felt moral obligation to integrity and to society, and the board will have done the country an inestimable service.

The SABPP has done valuable work to establish good governance and ethical principles, develop levels, categories and criteria, establish continued professional development and a strong research arm. This has led to a better understanding of acceptable standards of practice in HR management.

The SABPP deserves commendation for its groundbreaking work.

\section{References}

Babbie, E., \& Mouton, J. (2006). The practice of social research. Cape Town: Oxford University Press.

Bryman, A., \& Bell, E. (2003). Breaking down the quantitative/qualitative divide. In A. Bryman \& E. Bell (Eds.), Business Research Methods, (pp. 465-478). Oxford: Oxford University Press.

CCHRA. (2007). Official website of the Canadian Council of Human Resources Associations. Retrieved 22 April 2007, from www.cchra.ca

CIPD, (2007). Official website of the Chartered Institute of Personnel and Development. Retrieved 19 August 2007, from www.cipd.co.uk.

Georgia Institute of Technology. (2008). Qualitative Methods Reminder. Retrieved 01 December 2008, from hcc.cc.gatech.edu/getDocument.php?doc $=63$

Hancock, B. (2002). Introduction to qualitative research. Retrieved 02 December 2008, from www.trentrdsu.org.uk/cms/uploads/Qualitative\%20Research.pdf

$\mathrm{HRCl}$. (2004). Official website of the Human Resource Certification Institute, an affiliate of the Society for Human Resource Management. Retrieved December 22, 2007, from http://www.hrci.org

Heneman, H. (1948). Qualifying the Professional Industrial relations Worker. Retrieved December 01, 2008, from http://www.findarticles.com/p/articles/mi_m3495/ is_n11_v38/ai_14837381

Langenhoven, H.P., \& Daniels H.F. (1980). Investigation on the professionalisation of expert personnel management. Department of Industrial Psychology Personne Research Division. Bloemfontein: University of the Free State.

Leonard, B. (2004). A brief history of HRCI. Retrieved December 01, 2008, from http:// www.hrci.org/AboutUs/HISTORY

Meyer, M. (ed). (2011). Wisdom from HR Mentors. Johannesburg: SABPP/Knowledge Resources.

Mishoe, S.C. (2003). Critical thinking in respiratory care practice. A qualitative research study. Retrieved June 01, 2010, from http://www.rcjournal.com/ abstracts/1996/?id=A00001283

Rossman, G.B., \& Rallis, S.F. (1998). Learning in the field: An introduction to qualitative research. Thousand Oaks, CA: Sage Publications.

Strauss, A., \& Corbin, J. (1990). Basics of Qualitative Research: Grounded Theory Procedures and Techniques. Newbury Park: Sage Publications.

Tracey, W.R. (1998). The Human Resources Glossary. Washington, D.C: St. Lucie Press.

Trauth, E.M. (2001). Qualitative research in IS: issues and trends. Hershey: Idea Group Publishing.

Trochim, W.M.K. (2006). Introduction to Design. Retrieved June 01, 2010, from http:// www.socialresearchmethods.net/kb/desintro.htm

Ungerer, M., Herholdt, J., \& Uys, K. (2006). Leveraging knowledge-based Assets - The New Value Equation to Create Competitive Advantage. Johannesburg: Knowres.

Van Rensburg, A.H. (2009). Human resource management as a profession in South Africa. Unpublished MPhil dissertation, University of Pretoria, Pretoria. 